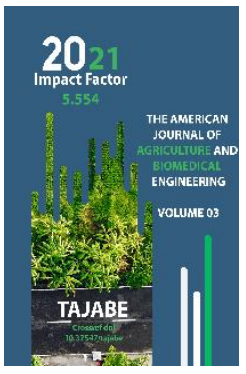

\title{
The Prtotein Content In Edible Insects And The Nutritional Value Of Macrophytes In Their Diet
}

\author{
Sattarov Abdumurod Sattarovich \\ B.S.Dos. Termez State University, Uzbekistan
}

Journal Website:

http://theamericanjour nals.com/index.php/taj abe

Copyright: Original content from this work may be used under the terms of the creative commons attributes 4.0 licence.

\section{ABSTRACT}

This article analyzes the synthesis of the Tenebrio molitor protein (Coleoptera: Tenebrionidae) belonging to a food insect, depending on its nutrient content. Differences in protein synthesis by Tenebrio molitor larvae were shown when wheat bran and flour from the macrophytesLemna minor and Azollacarolina were added. In particular, it was noted that TMO-2 and TMO-6 T.molitor F6 larvae are synthesized on average $31.02 \%$ protein in wheat bran, $38.13 \%$ in duckweed and $30.87 \%$ in azole. It was found that the larvae of variant F6 grown on wheat bran synthesized protein on average $4.79 \%$ less than the variant F1 of wheat. F6 larvae grown in duckweed synthesized $7.11 \%$ more protein than larvae grown in wheat bran and $0.15 \%$ less protein synthesis than larvae grown in azole. It was found that F6 larvae grown in duckweed produce $7.26 \%$ more protein than larvae grown in azole. Summarizing these indicators, it was noted that in the body of larvae eating macrophytes insufficient absorption of nutrients, low moisture content in the feed led to their death, egg laying and larvae of variant F6 produced significantly less protein than variant F1. When feeding macrophytes, it is advisable to takeintoaccountits moisture content or add flour based on them to other food sources. It was studied that egg-laying larvae grown on the basis of azole accounted for $38.14 \%$, whereas in duckweed this indicator was $58.38 \%$. It was found that in larvae grown on wheat bran, the percentage of egg-laying is $68.85 \%$. The mortality rate of larvae feeding on wheat bran was $18.22 \%$, in duckweed $-44.63 \%$, in azole $-62.27 \%$, this is due to insufficient moisture in the composition of duckweed and azole (average humidity 3.4-4.2\%), relatively high humidity (average humidity 9.58$10.12 \%$ ) in wheat bran. Survival coefficients of Tenebrio molitor F6 larvae were determined in three different compositions and sources of nutrients with different humidity (wheat bran, Lemna minor and flour Azollacarolina). Tenebrio molitor F6 larvae of the generation of variants TMO-2 and TMO-6 were grown on wheat bran with an average survival rate of 0.79 , on duckweed flour -0.50 , on azolla flour - 0.64. It was noted that the survival rate of larvae grown on wheat bran was $15.5 \%$ higher than that of larvae grown on azolla, and it is advisable to explain the source not by the protein reserve, but by the amount of moisture in it. It was noted that the moisture content (9.58-10.12\%) (protein 
$15 \%$ ) in wheat bran was a factor in the high viability of the larvae compared to azolla (protein-27\%, humidity $8.2 \%$ ). Despite the easy protein synthesis in the body of larvae in duckweed flour (protein $16.1 \%$, humidity $-4.4 \%$ ) compared to azolla flour, its content is $3.8 \%$ lower than that of azolla, due to the fact that survival the larvae in them were lower than in wheat and azolla. Therefore, along with the protein content, moisture is an important factor when choosing a food source. When summing the survival rates of larvae of the Tenebrio molitor F6 generation in the studied nutrient media, the average survival was calculated as 0.96 . This means that based on the established ratios of wheat bran, duckweed and azolla flour, it will be possible to create a nutrient medium with a new content, high nutritional value low cost

\section{KEYWORDS}

Tenebrio molitor, yellow mealworm, edible insects, insects feed, fish feed, protein, amino acid, macrophytes, Lemna minor, Azollacarolina.

\section{INTRODUCTION}

By 2050, there will be a problem with the provision of food to more than 9 billion people [FAO, 2009]. According to FAO (2011), by 2050 , compared with 2010, the demand for meat products will increase by $58 \%$, and the demand for dairy products - by $70 \%$. Livestock farming is known to be one of the most productive sectors, with $35 \%$ of world production and $75 \%$ of agricultural production spent on developing this industry. Also, this industry consumes $8 \%$ of the world's drinking water (including food crops) [FAO/WUR, 2014; Foley et al., 2011]. In addition, the livestock sector emits $14.5 \%$ of all anthropogenic greenhouse gases, which is about 7.1 gigatons of $\mathrm{CO}_{2}$ equivalent per year [Gerber et al., 2013]. Livestock farming also requires a large amount of water [Mekonnenand Hoekstra, 2012]. As a result, the cultivation of livestock products requires huge reserve resources, taking into account the production of feed. This shows that the cultivation of foods that are easy to manufacture, inexpensive and rich in all the

necessary ingredients is one of the most pressing problems.In addition, soybean flour and fishmeal are recognized separately as the main food sources to provide the fishing industry with nutritious food products in the global industry. Wheat flour and corn flour are also widely used as staple foods in fisheries. It is noted that soy flour contains $44-54 \%$ protein and 2-3\% fat [Adámková et al., 2016], while fish meal contains about 48-75\% protein and 9-11\% fat [Vrabec et al., 2015].

One of the global problems is a sharp change in the natural climate, drought due to abiotic and biotic factors, a decrease in the area of land for agricultural production due to increased salinity and soil degradation, and serious problems arise in the production of agricultural products under the influence of various pests and diseases.

By breeding industrially insects with a nutritious chemical composition, it is possible 
to create an unlimited number of feed industries and feed additives for livestock production [van Huis et al., 2013]. The fact that it is very convenient to breed insects on the basis of inexpensive secondary organic products or on the basis of biological waste shows the importance of these biological objects [Collavo et al., 2005].

Insects can also consume various processed wastes, turning them into food feeds with high nutritional value. It was shown that, reproducing a large number of insects on an industrial basis, they can be used as an alternative to the production of food products with high nutritional value [Veldkamp et al., 2012]. In particular, it was determined that Tenebrio molitor (larva) of various food insects retains $44-64 \%$ protein, $17-43 \%$ fat [Finke, 2002], 40-75\% protein [Bukkens, 1997], Alphitobiusdiaperinus (larva) - protein 58-65\%, fat 22-29\% [Diener et al., 2009], Achetadomestica (adult) - protein $58-74 \%$, fat 14-23\% [Oonincx\& van der Poel., 2011], Gryllodessigillatus (adult)) - protein 70\%, fat $18 \%$ [Ravzanaadii et al., 2012] Locustamigratoria (adult) - protein 56-65\%, fat $13-30 \%$, Hermetiaillucens (larvae) - protein 32$52 \%$ fat $12-42 \%$ [Rumpold\&Schlüter, 2013].Thus, food insects can be considered as an alternative source of providing the livestock, poultry, and fishing industries with a continuous nutritious food base [Khujamshukurov., 2011].It is known that Tenebrio molitor is one of the most widely used food insects in the world practice [Khujamshukurov et al., 2016].

In addition, the amino acids in their protein [Akhtar and Isman., 2018] and the fatty acid content of their fat are also interpreted differently [Boscou et al., 2006; Caruso et al., 2014; Jeon et al., 2016; Jokic et al., 2013; Popa et al., 2012]. This may be due to the area of distribution of these insects, living conditions, type of feeding under controlled conditions, nutritional value of the food base.

Studying the economic and environmental aspects of food insects allows them to be widely used. In particular, the high protein supply of insects and the fact that they consume less food than other sources allow us to consider them as an economically sustainable alternative source. The production of protein products based on food insects is explained by a high economic profitability than the production of protein products based on livestock and poultry [Van Huis., 2013]. In particular, if at least $20 \mathrm{~kg}$ of corn and soybeans are required per kilogram of beef [Smil, 2002], food insects such as locusts will need $2 \mathrm{~kg}$ of feed to produce one kilogram of protein [Khujamshukurov et al., 2016]. At the same time, it is very important that food insects consume less water than livestock [Steinfeld et al., 2006]. To obtain products based on cattle, fishmeal, bone meal, sunflower, cotton and soy protein and even animal blood are added to feed products to enrich their feed composition. This leads to an increase in the cost of these feed products and a sharp decrease in their economic profitability [Tran et al., 2015; Van Huis et al., 2013.].

When growing protein products based on food insects, it is possible to organize the process of their environmentally friendly production compared to cattle, pigs and poultry [Khujamshukurov, 2011]. The relatively low level of greenhouse gases, including methane, nitrogen oxides, and carbon dioxide, which form food insects than livestock, play an important role in maintaining environmental sustainability [Oonincx et al., 2010]. It is also possible to breed insects under controlled conditions and 
start a small business without attracting large amounts of money [Berggren et al., 2019]. It also ensures that farms organize their own production, get high protein foods and lower their cost. The high protein content in food insects and the presence in them of all the necessary amino acids determine the nutritional value of the food products on which they are based. For example, one of these food insects is the flour beetle (Tenebrio molitor), which stores protein and is rich in amino acids, including a high level of essential amino acids, such as lysine and methionine [Ekpo, 2011]. According to scientific sources, this food insect with respect to dry matter contains $40-75 \mathrm{~g} / 100 \mathrm{~g}$ of protein, 7-77 g/10og of fat and 3-8 g/100 g of minerals [Bukkens et al., 2005; Ramos-ElorduyBlasquez et al., 2012; Ramos-Elorduy et al., 1997; Rumpold et al., 2013]. Some scientific sources have shown that Tenebrio molitor contains $51 \%$ protein, $32 \%$ fat and up to $5 \%$ minerals compared to dry matter [Zieli'nska et al., 2015].

In addition, the composition of many food insects is rich in lipids (up to $27.4 \%$ ), which can be used to enrich various lipid-based products, to obtain lipid-based drugs, or as a source in the production of alternative sources, including biodiesel. Studies have shown that when 20\% Tenebrio molitor is added to flour for food, the lipid content increases from $0.9 \%$ to $5.4 \%$ [Azzollini et al., 2018]. The composition of food insects is also rich in fatty acids [Zhao et al., 2019]. Although the vitamin retinol in food insects is very low compared to other sources, it is very rich in vitamins such as riboflavin, pantothenic acid and biotin, which determine its nutritional value. Some studies also report high levels of folic acid [Rumpold et al., 2013]. As promising food insects, like Schistocercagregaria is characterized by protein content up to $76 \%$ in relation to dry matter, and tropical locusts Gryllodessigillatus - up to $70 \%$. If we compare these figures with serum $(\sim 87 \%)$ and chicken egg protein $(\sim$ $82.1 \%)$, we will see that they are very important [Kamler et al., 2012]. According to the FAO, the amount of methionine and cysteine amino acids in locusts is equal to daily human consumption [Zieli'nska et al, 2015]. It is also reported that the minerals in food insects are larger in comparison with other objects, such as beef $\sim 6 \mathrm{mg} / 100 \mathrm{~g}$, in locusts $8 \mathrm{mg} / 100 \mathrm{~g}$. While the fat content in milk powder is about $26 \%$, in the beetle this indicator is about 25\% [Fitzpatrick et al., 2004].

The practice of obtaining protein products from food insects and their use in poultry and fisheries has not yet become widespread in the Republic of Uzbekistan. There are several reasons for this:

First, as in world practice, it is difficult to study new food sources and apply them in everyday practice;

The second - the ethnic mentality of the local population is sharply affected;

Thirdly, the staff of consumer farms does not have enough information about food insects, their importance, nutritional value, ease of production and guidelines for their use in the religious beliefs of the local population;

Fourth, the manufacturing sectors were provided with sufficient sources of production and so on.

After the independence of the Republic of Uzbekistan (1991), livestock, poultry and fishing developed rapidly, small enterprises were established, and the demand for 
nutritious and inexpensive food products at the local level grew several hundred times.

In particular, 600 tons of wheat used in the food industry in 2018 was allocated only to the fishing industry. The main reason for this is that, under local conditions, wheat does not stand out as a source of food and feed. In addition, high-protein crops such as barley, corn and soybeans are not grown as large plantations. In addition, fish products and their processing industry, sufficient for the production of fishmeal, are under development. In particular, it was planned to grow about 6-9 tons of fish in 1996-2009, 72 tons in 2010-2017, 82 tons in 2018, 150 tons in 2019 and about 200 tons in 2020 [Decree of the President of the Republic of Uzbekistan, 2017].

Therefore, one of the most important tasks is the development of the fishing industry in the local context, the creation of a continuous feed base for this industry with high nutritional and nutritional value.

It is known that a large number of food products are used in the cultivation of food insect species. These include products such as soy flour, corn flour and bran, wheat bran or cereal products, flour and bran, depending on the conditions of the region in different countries. Since these products are mainly food for human consumption, one of the important tasks is the search and study of alternative sources of their replacement.

In 2001, the FAO noted that in Uzbekistan, based on macrophytes Lemna minor of the genus Lemnaceae, they can produce 7-15 $\mathrm{t} / \mathrm{ha}$ / year [FAO, 2001], based on our scientific studies, it was proved that in Uzbekistan it is possible to obtain $154 \mathrm{t}$ / ha / year wet biomass or 27.34 tons of dry weight. This is due to favorable weather conditions in Uzbekistan, the fact that the number of sunny days is almost 308 days, the possibility of continued growth of macrophytes from March to November.

The production of industrial products based on the Lemnaceae family is widespread, one of the main ones is duckweed flour, fatty acidrich ingredients, various feed additives for poultry, protein feed for fish [Haustein et al., 1994; Bairagi et al., 2002]. It was noted that flour made on the basis of macrophytes belonging to the genus Lemna contains 35-45\% of crude protein and $7-10 \%$ of fibrillar fibers [Olorunfemi et al., 2009; Hasan and Chakrabarti, 2009; Rojas et al., 2014]. Therefore, when growing food insects from macrophytes, the preparation of feed or feed additives and their widespread use in practice is of great scientific and practical importance.

\section{THE PURPOSE OF THE WORK}

Growing in the conditions of Uzbekistan consists in determining the stock of proteinTenebrio molitor (Coleoptera: Tenebrionidae) and in macrophytes grown in Uzbekistan and the dynamics of their egg laying.

\section{RESEARCH METHODS}

(Including equipment). Object of study. The sixth generation (F6) Tenebrio molitor (Coleoptera: Tenebrionidae) was used, collected from the southern foothills of Uzbekistan and propagated under controlled conditions. In the course of the study, from the numbered larvae and beetles of Tenebrio molitor (128: larvae 108, 20 beetles) collected from nature, after visual observation, we selected 2 largest in size compared to others (TMO-2: $5.36 \mathrm{~cm}$, TMO-6: $4.83 \mathrm{~cm}$ ), (F1 
variant), on the basis of which the Tenebrio molitor colony was formed. Growing conditions: wheat bran with a standard content (protein 14-15\%, fat 0.8-1.0\%), as well as Lemna minor from macrophytes (protein $16.1 \%$, fat $2.8-3.1 \%$ ) and used the dry biomass of Azollacarolina (protein -27.6\%, fat-2.8-3.2\%). Temperature 20-22 ?C. In this study, F1-based variants of TMO-2 and TMO-6 larvae based on F6 variant were used to determine viability characteristics on various nutrient media that are produced by the protein and to study the rate of their laying. Variants of Tenebrio molitor TMO-2 and TMO-6 larvae were used as control for each other when analyzing protein formation in various nutrient sources. The duration of cultivation in all samples was 28 days.

Determination of proteins. Method R. Scoups (1985) was used in protein purification. During protein separation, the dry mass of the insect was crushed and disinfected with hexane. They took $1.5 \mathrm{~g}$ of insect flour and extracted sequentially in $5 \mathrm{ml}$ of water, $5 \mathrm{ml}$ of $5 \mathrm{M}$ sodium chloride, $5 \mathrm{ml}$ of absolute methanol and $5 \mathrm{ml}$ of $0.2 \mathrm{M}$ phosphate buffer ( $\mathrm{pH}-8.0)$. Each extraction was carried out for 20 minutes. After extraction, the solutions were centrifuged for $15 \mathrm{~min}$ at a speed of $8000 \mathrm{rpm}$. The amount of protein in the supernatant was determined by the standard Lowry method. The calculation of the statistical error, mean value, confidence intervals and standard deviations from experimental data was carried out using the STATISTICA 6.0 computer program and standard methods. The statistical significance of the results was determined using Student's t-test.

\section{RESULTS AND THEIR DISCUSSION}

When studying the direct storage of protein of Tenebrio molitor larvae (3-4 cm long), variant F1 collected from the Angren mountain ranges, Republic of Uzbekistan, Tashkent region, the average protein content was $43.09 \%$ (Figure 1). It was noted that the average protein content in the variants of $\mathrm{F} 1$ larvae $1-3 \mathrm{~cm}$ long collected from nature is $42.74 \%$ (Fig. 2).

The average protein content in both variants was summed up and averaged $43.0 \%$. This indicator (43.0\%) was used as a control for moderate growth of Tenebrio molitor larvae and selection of culture media with different protein contents for storage. During the study, from larvae and beetles collected by nature and numbered Tenebrio molitor (128: larvae 108, 20 beetles), 2 larvae (TMO-2: 5.36 $\mathrm{cm}$, TMO-6: $4.83 \mathrm{~cm}$ ) were selected (F1 variant), which were the largest in size compared to others, upon visual observation, a Tenebrio molitor colony was formed on their basis. 


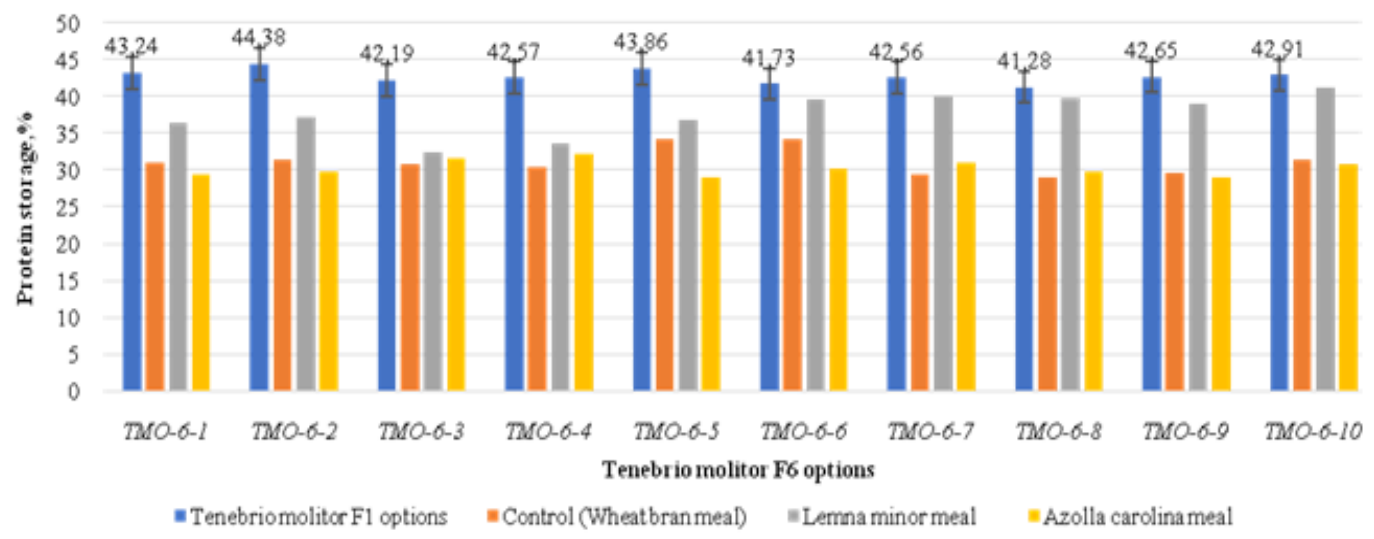

Figure 1. Storage of Tenebrio molitor larvae protein (TMO-2) in various nutrient media (\% of dry matter)

Note - option F1 is a variant collected from nature; Wheat bran: protein $14-15 \%$, fat $0.8-1.0 \%$; Duckweed: protein $16.1 \%$, fat $2.8-3.1 \%$; Azolla: protein $-27.6 \%$, fat- $2.8-3.2 \%$.

In this study, variants of TMO-2 and TMO-6 larvae based on variant $F_{1}$ and based on $F_{6}$ were used to study the properties of protein formation in various nutrient sources. Variants of Tenebrio molitor TMO-2 and TMO-6 larvae were used as controls for each other in the analysis of protein formation in various nutrient sources.

Although the larvae of the TMO-2 variant obtained on the basis of the $F_{6}$ variant synthesized $30.89 \%$ of the protein in wheat bran, it was found that they synthesize $12.2 \%$ less protein than in the control variant $\left(F_{1}\right)$. The TMO-2 variant grown in duckweed-based nutrient medium showed an average of $38.65 \%$ protein synthesis, $4.44 \%$ less than the $F_{1}$ control, and $7.71 \%$ more protein synthesis than $F_{6}$ grown on wheat bran. Therefore, the fact that duckweed stores more protein than wheat bran from the point of view of protein storage, could serve as the basis for this. It was found that the larvae of the TMO-2 variant obtained on the basis of variant $F_{6}$ synthesize

an average of $31.48 \%$ of the protein when grown on the basis of azole.

It was noted that the protein synthesized is $11.61 \%$ less compared to the $F_{1}$ protein variant. It was found that wheat bran produces an average of $0.59 \%$ more protein than the larvae of variant $F_{6}$, and $7.17 \%$ less protein synthesis than the larvae of variant $F_{6}$ grown in duckweed. The fact that less protein is synthesized in azole than in duckweed can be explained by the fact that splitting of the azole flour in the larval organism is more complicated than in duckweed flour.

The larvae of the TMO-6 Tenebrio molitor variant obtained on the basis of $F_{6}$ synthesized $31.15 \%$ of the protein in wheat bran, while protein synthesis was observed to be $11.59 \%$ less compared to the control variant $\left(F_{1}\right)$ (Fig. 2). The TMO-6 variant grown in a nutrient medium based on Lemna minor synthesized an 
average of $37.60 \%$ protein, $5.14 \%$ less than the $F_{1}$ control, and $6.45 \%$ more protein synthesis than the $F_{6}$ variant grown on wheat bran. Therefore, the reason for this may be the fact that the aforementioned duckweed stores more protein than wheat bran. It was observed that the larvae of the TMO- 6 variant obtained on the basis of the $F_{6}$ variant synthesized on average $30.26 \%$ of the protein when grown on the basis of azole and $12.48 \%$ less protein synthesis than on the $F_{1}$ control. Variant TMO-6 larvae grown on Azollacarolina flour synthesized $0.89 \%$ less protein than larvae of TMO-6 variant grown on wheat bran.

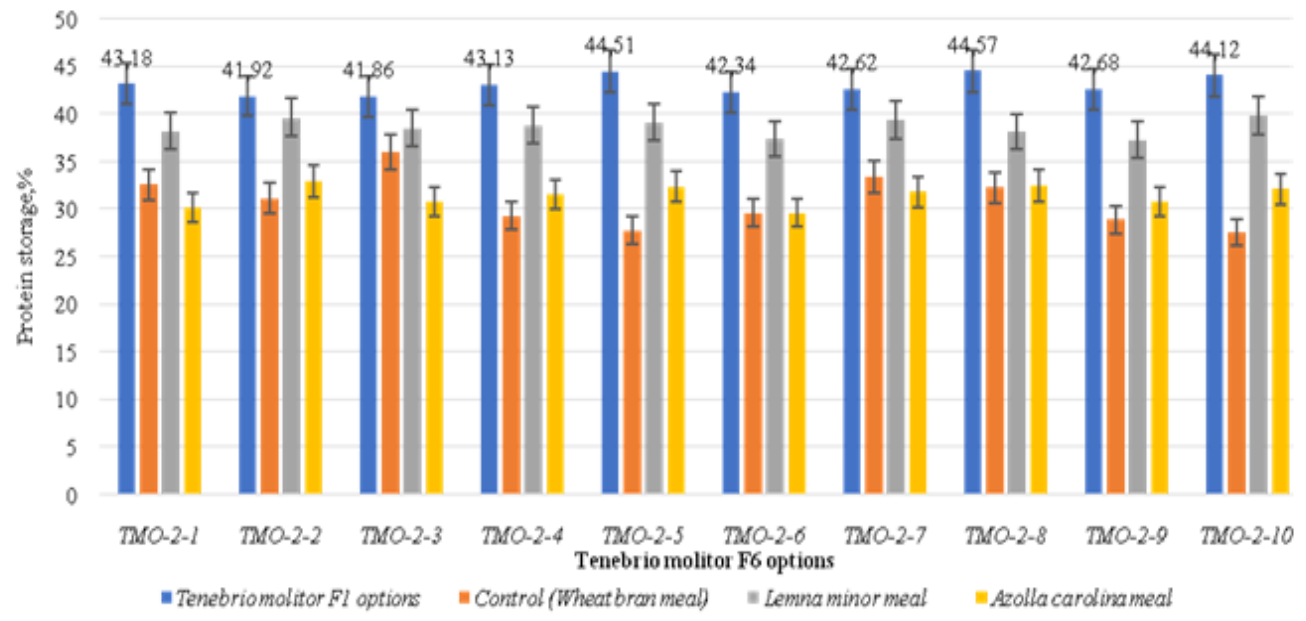

Figure 2. Storage of protein larvae of Tenebrio molitor (TMO-6) in various nutrient media (in \% of dry matter)

Note - option F1 is a variant collected from nature; Wheat bran: protein $14-15 \%$, fat $-0.8-1.0 \%$; Duckweed: protein $16.1 \%$, fat - 2.8-3.1\%; Azolla: protein - $27.6 \%$, fat $-2.8-3.2 \%$

The results obtained compared the synthesis of $\mathrm{F}_{6}$ protein of the larva variant of TMO-2 and the variant TMO-6 in food sources with an average protein synthesis of $31.02 \%$ in standard wheat bran, $38.13 \%$ in duckweed and $30.87 \%$ in azole. It was found that the larvae of variant $F_{6}$ grown on wheat bran synthesized protein on average $4.79 \%$ less than variant $F_{1}$. $F_{6}$ larvae grown in duckweed synthesized $7.11 \%$ more protein than larvae grown in wheat bran and $0.15 \%$ less protein synthesis than larvae grown in azole. It was found that $F_{6}$ larvae grown in duckweed produce $7.26 \%$ more protein than larvae grown in azole. This means that although the source of the nutrients of the naturally harvested $\left(F_{1}\right)$ larvae is unclear, they may have had high protein synthesis because

they naturally fed on the most convenient and nutritious food source. The high protein synthesis of $F_{6}$ larvae in wheat bran compared to duckweed can be explained by its high protein content and its easy digestion in the larval organism. However, the high protein content in azole can be explained by the fact that the larvae synthesize less protein than duckweed, which complicates the breakdown and digestion of azole in the larval organism.

However, studies have shown significant differences in the overall development and mortality of larvae feeding on duckweed and 
azole. In particular, the laying of eggs of larvae based on azole was 38.14\%, and in duckweed $58.38 \%$. It was noted that the percentage of egg laying in larvae grown on wheat bran was $68.85 \%$.The mortality rate of larvae feeding on wheat bran was only $18.22 \%$, on duckweed $44.63 \%$, and on azole $-62.27 \%$. This situation is explained by the fact that in duckweed and azole there is not enough moisture (average humidity $3.4-4.2 \%$ ), the content of wheat bran is relatively high (average humidity 9.58$10.12 \%)$.

Summing up these indicators, we believe that the lack of nutrients in the body eating macrophyte larvae, the low moisture content in the feed led to their death, egg laying and larvae of variant $F_{6}$ produced significantly less protein than variant $F_{1}$. Therefore, when feeding macrophytes, it is advisable to take into account its moisture content or add flour based on them to other food sources. Then the larvae can die, lay eggs and achieve maximum protein synthesis.In this study, variants of TMO-2 and TMO-6 larvae based on $F_{1}$ variant obtained on the basis of $F_{1}$ were used to study the properties of protein formation in various sources of nutrients.Variants of Tenebrio molitor TMO-2 and TMO-6 larvae were used as controls for each other in the analysis of viability characteristics in various nutrient sources.

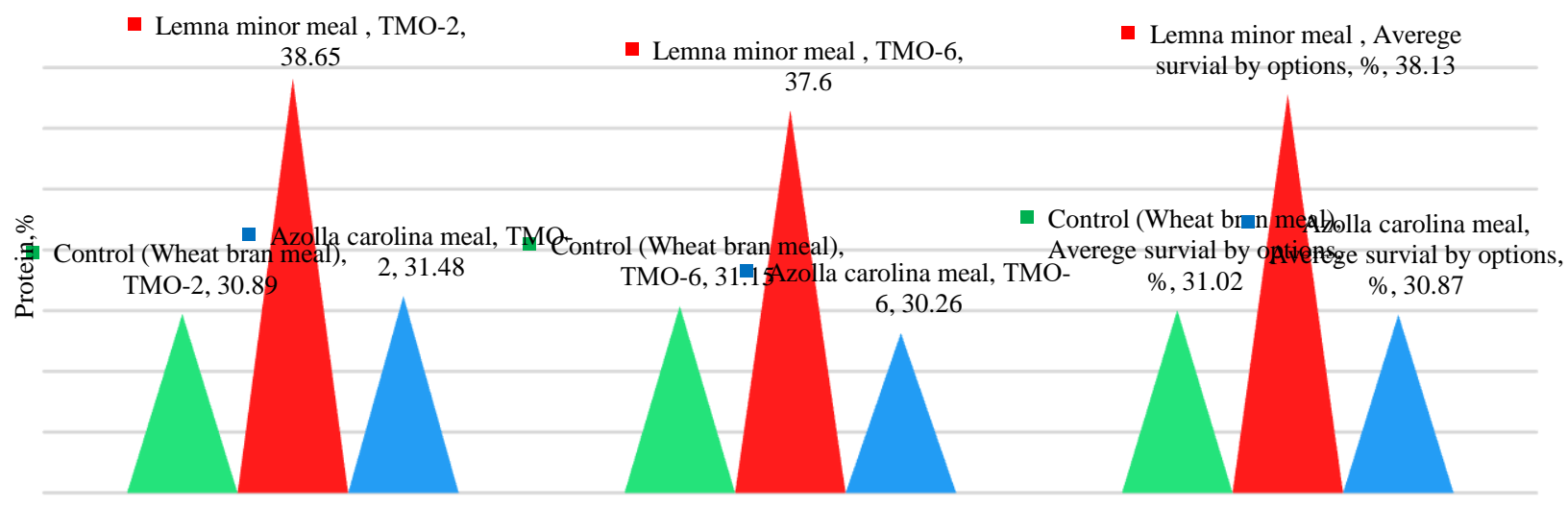

Experiment options

- Control (Wheat bran meal)

- Lemna minor meal

- Azolla carolina meal

Figure 3. Protein formation of Tenebrio molitor $\left(F_{6}\right)$ larvae in different nutrient content (relative to dry matter,\%)

In Figure 3 shows the average protein synthesis of the larvae of the TMO-2 and TMO6 variant obtained from the $F_{6}$ generation in different nutrient sources (Fig. 4). It was observed that the larvae of the TMO-2 $\left(\mathrm{F}_{6}\right)$ variant have different levels of protein synthesis when grown in various feeds, including $30.89 \%$ in

wheat bran, $38.65 \%$ in duckweed, and $31.48 \%$ in azolla.It was noted that when growing larvae of the TMO-6 $\left(\mathrm{F}_{6}\right)$ variant in nutrient media of the same composition, $31.15 \%$ of the protein 
was synthesized in wheat bran, $37.60 \%$ in duckweed, and $30.26 \%$ in azolla. According to the results of general nutrient media, $31.02 \%$ of protein synthesis in wheat bran, $38.13 \%$ in duckweed and $30.87 \%$ in azolla compared to dry matter.

According to a generalized analysis of the TMO-2 and TMO- 6 variants from the Tenebrio molitor $\mathrm{F}_{6}$ generation, larvae grown on wheat bran synthesized $6.98 \%$ more protein than duckweed and $0.15 \%$ more protein than larvae grown in azolla. It was found that the larvae of the TMO-2 and TMO-6 variant grown in duckweed synthesize $6.98 \%$ more protein than wheat bran and $7.26 \%$ more protein than the larvae grown in azolla. This can be explained, first of all, by the fact that flour based on azolla and wheat bran are more difficult to break down in the body of larvae than duckweed. Secondly, this can be explained by the insufficient moisture content in the flour based on azolla and the relatively low protein content in wheat bran.

The fact that the larvae of the TMO-2 and TMO-6 variants from the $\mathrm{F}_{6}$ Tenebrio molitor generation synthesized proteins with different characteristics in different sources of nutrients suggests the need to study the viability of these larvae in these nutrient sources. The viability characteristics of the larvae of the TMO-2 variant based on wheat bran are shown in Figure 4. When the viability of TMO-2 larvae in wheat bran was studied on the basis of 300 larvae (30 of them, 10 variants), it was noted that their average viability was $72.33 \%$. The daily survival of larval variants was observed, while the average survival rate was $1.0 \%$ in the first ten days (results of 5-10 days) and a 5\% decrease on the 15 th day. On the 20th day of observations, the larval survival rate was $83 \%$ and decreased by $11 \%$ between 15 and 20 days. A further decrease of $9.33 \%$ was observed between $20-$ 25 days of observation, while the decrease was $1.34 \%$ between $25-28$ days, with an average survival rate of $72.33 \%$ in the medium. Thus, the average survival of the larvae of the TMO-2 variant in this nutrient medium was $0.72 \%$.

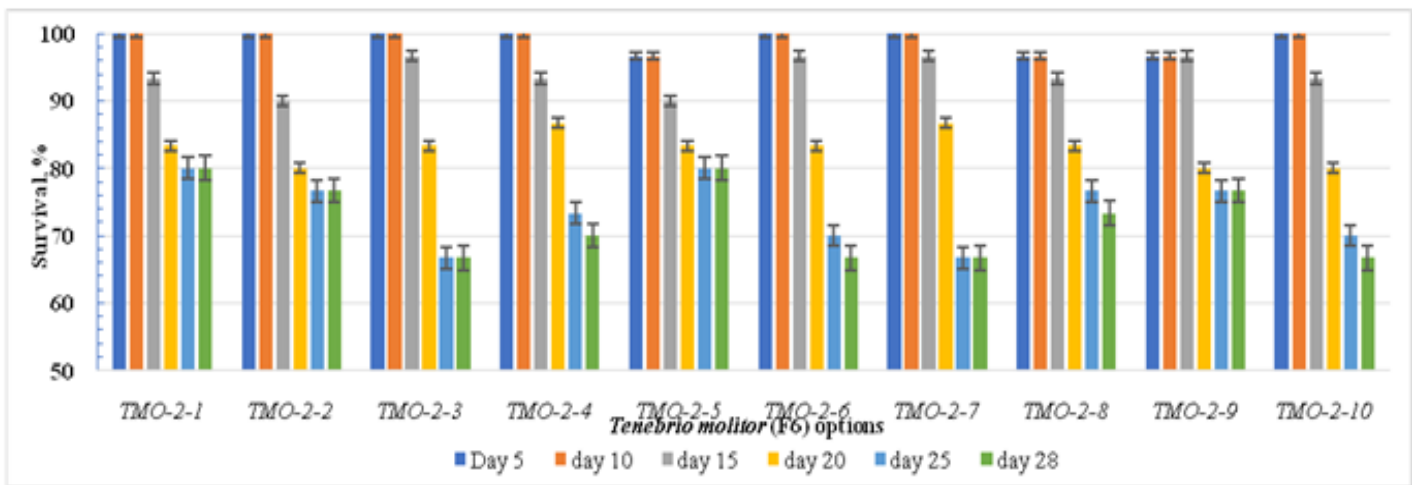

Figure 4. Survival of Tenebrio molitor larvae (TMO-2) in wheat bran (control), $\%$ 
It was noted that the average survival of the larvae of the TMO- 6 variant grown on wheat bran averaged $87.33 \%$ (Fig. 5). When analyzing

TMO-6 variant larvae in the variant section, it was found that the average survival rate in the first ten days was $99 \%$ on average and decreased to $94 \%$ on the 15 th day of observation. In wheat bran, the larvae of the TMO-2 variant lost $17 \%$ viability in 20 days, while the larvae of TMO- 6 lost only $7.67 \%$ over this period. The larvae of the TMO-6 variant lost viability by $11.33 \%$ by the 25 th day of observation, while the TMO-2 variant lost viability by $26.33 \%$ at that time.

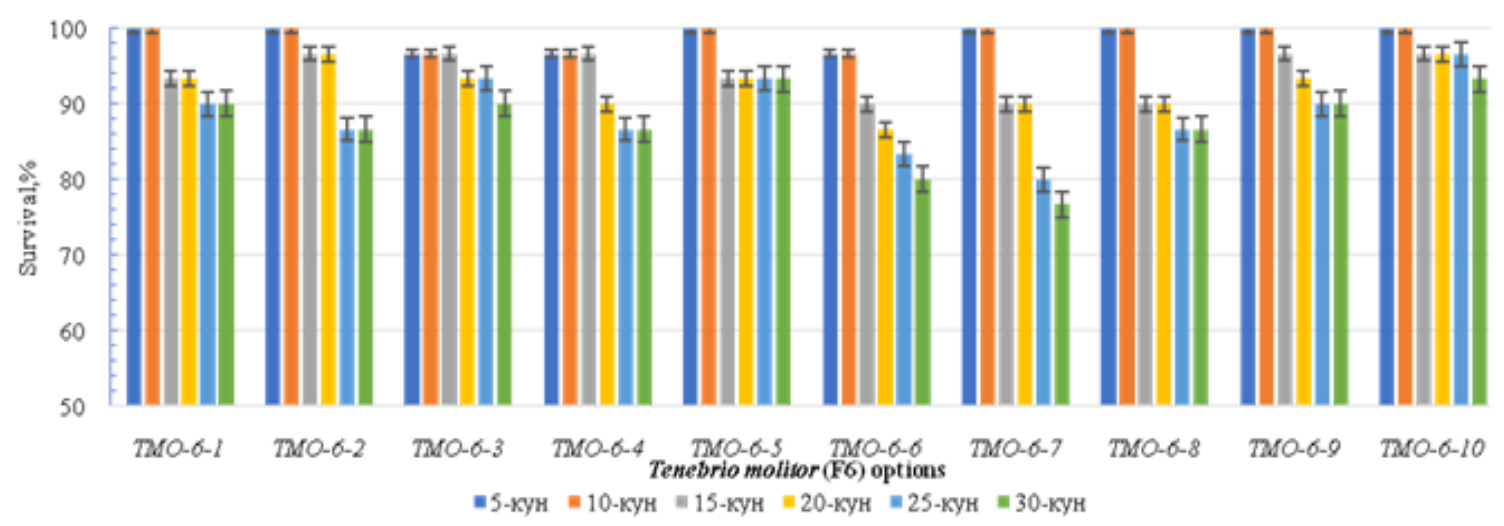

Figure 5. Survival of Tenebrio molitor larvae (TMO-6) in wheat bran (control), $\%$

By the 28th day of observation, the larvae of the TMO-6 variant lost $12.67 \%$ of their viability, while by this time the TMO-2 variant lost $27.67 \%$ of their viability. It was also noted that in the analysis from the point of view of the internal variants of TMO-2 and TMO-6, the TMO-2 variant lost $15 \%$ more viability than the TMO-6 variant. Therefore, it can be assumed that the adaptability of each larval variant to the composition of the nutrient medium will also vary. The analysis of the nutrient medium (wheat bran) showed that the generalized average survival of the larvae of the TMO-2 and TMO-6 variants was $79.83 \%$. In wheat bran, the survival rate of larvae of the Tenebrio molitor $F_{6}$ generation can be estimated at $0.79 \%$.
In Figures 6-7 show the survival rates of the larvae of the TMO-2 and TMO- 6 variants obtained on the basis of the Tenebrio molitor $F_{6}$ generation obtained on the basis of the macrophyte Lemna minor.

It was noted that the larvae of the TMO-2 variant grown on the basis of duckweed flour lost less than $4 \%$ of viability in the first 10 days of observation compared with wheat bran (Fig. 6). By the 15th day of observation, survival dropped sharply (25.33\%). It was noted that survival was $19.33 \%$ higher than that of wheat bran. It was found that the larvae of the TMO-2 variant grown in duckweed lost about $40 \%$ viability by the 20 th day of observation, while the loss of survival was $23 \%$ higher than that of wheat bran. After 25 days of observation, the survival rate of 
TMO-2 larvae grown in duckweed was $56.33 \%$, which is $17.34 \%$ lower than the survival rate of larvae grown on wheat bran for 25 days. On the 28th day of the study, the survival rate of TMO-2 larvae grown on the basis of duckweed was $52.33 \%$, which is $20 \%$ lower than that of wheat bran (28th day).
Analysis of the larvae of the TMO- 6 variant on internal variants showed a $4.33 \%$ reduction in survival in the first ten days of the study. This indicator was $3.33 \%$ higher than for the TMO-2 and TMO-6 variants grown on wheat bran, and $0.3 \%$ higher than for the TMO-2 variant larvae grown on duckweed.

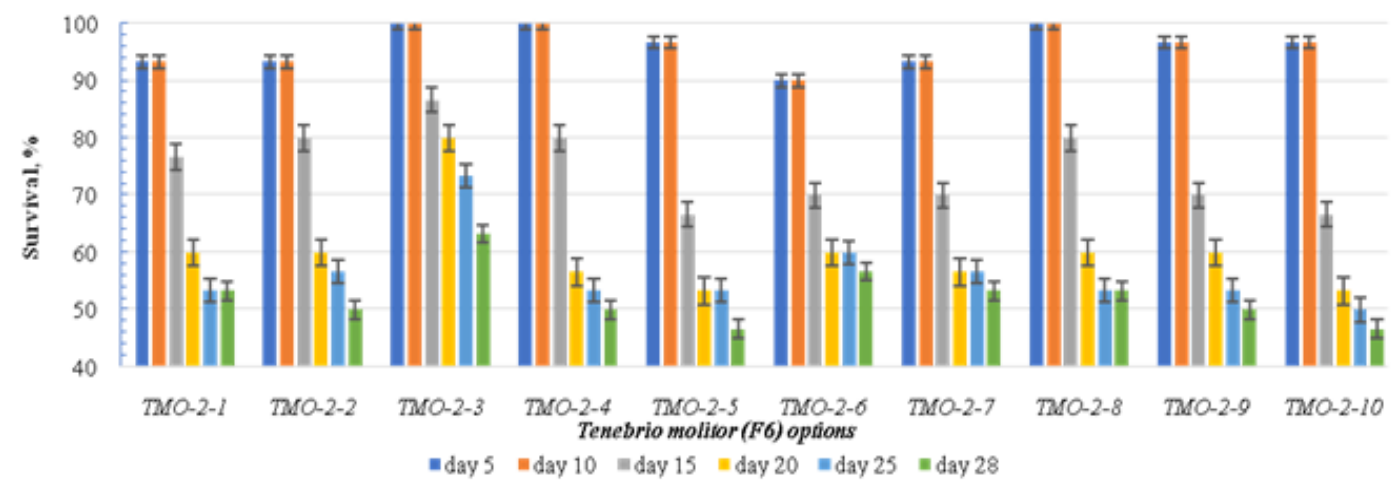

Figure 6. Life expectancy of Tenebrio molitor larvae (TMO-2) in Lemna minor flour, \%

The overall survival of the larvae of the TMO- 6 variant grown on the basis of duckweed was 48.67\% (Fig. 7).

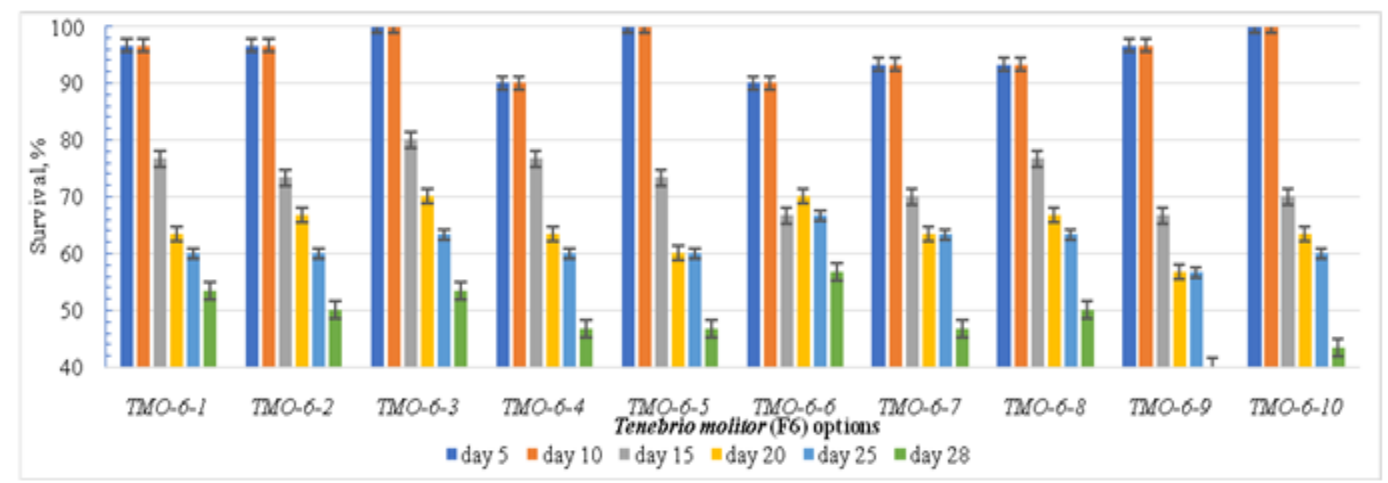

Figure 7. Life expectancy of Tenebrio molitor larvae (TMO-6) in Lemna minor flour, \%

In addition, the viability of the larvae of the TMO-6 variant grown in azolla on the 15th day of observation was $73.0 \%, 20.0 \%$ lower than that of the larvae of the TMO-2 and TMO- 6 variant grown on wheat, and $1.67 \%$ lower than the larvae of the TMO-2 variant grown in duckweed.

On the 2oth day of the study, the survival rate of larvae of the TMO- 6 variant grown in duckweed was $64.33 \%$, which is $23.17 \%$ lower 
than that of wheat bran and $4.33 \%$ higher than that of larvae of the TMO- variant 2 grown in duckweed. On the 25th day of observation, the average survival of larvae of the TMO- 6 variant grown in duckweed was $61.33 \%$, which is $19.84 \%$ lower than that of wheat larvae and $5.0 \%$ higher than that of TMO- 2 grown in duckweed. In the last 28 days of the study, TMO-6 was $3.66 \%$ less viable than TMO-2 grown in duckweed. The 28-day survival rate of the TMO- 6 variant was $48.67 \%$.
In addition, the viability of the larvae duckweed showed an average viability of $50.50 \%$. This figure was $29.33 \%$ lower than the viability of the larvae of this variant in wheat bran. The fact that the viability of a duckweedbased culture medium is lower than that of wheat bran can be explained by the very low moisture content in duckweed flour.

Figures 8-9 show the daily survival of the larvae of the TMO-2 variant and the TMO-6 Tenebrio molitor $\mathrm{F}_{6}$ variant in a nutrient medium made from Azollacarolina flour.

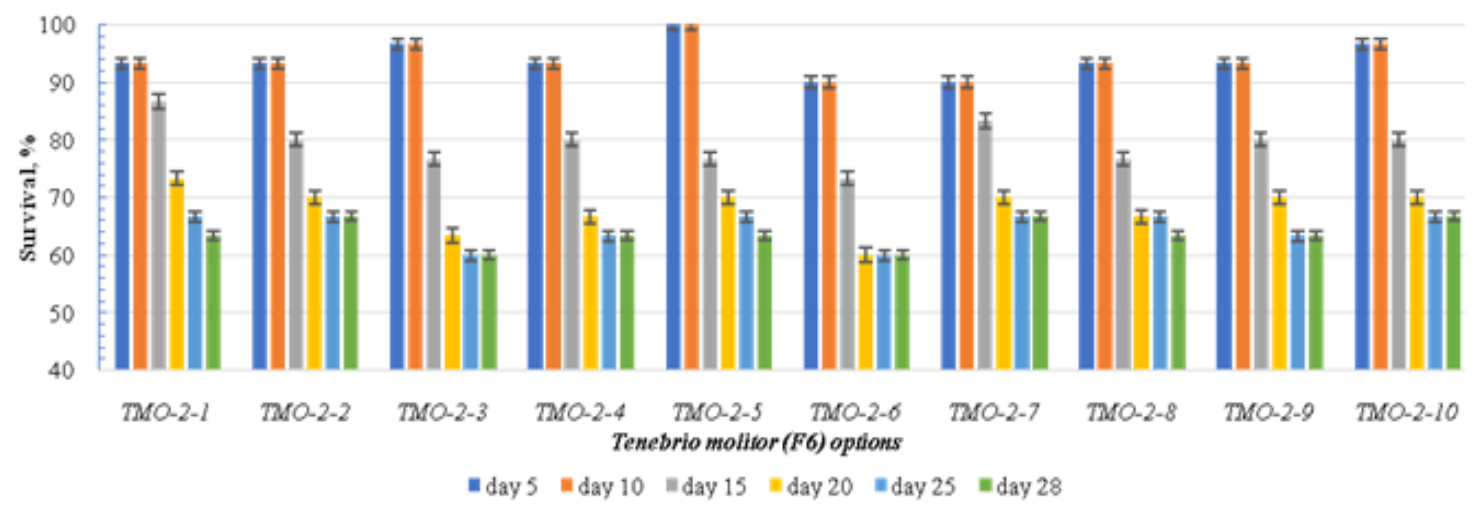

Figure 8. Survival of Tenebrio molitor larvae (TMO-2) in Azollacarolinaflour \%

The overall survival of larvae grown on the basis of Azollacarolina flour was $64.33 \%$ (Fig. 8). In particular, the survival of TMO-2 variant larvae was $94.0 \%$ in the first ten days of growth and $79.33 \%$ on the 15 th day of observation. This indicator was $14.67 \%$ lower than that of the larvae of the TMO-2 and TMO6 variant grown on wheat bran, while it was found that it was $5.49 \%$ more viable than the larvae grown on duckweed.

The larvae of the TMO-2 variant grown in azolla showed a survival rate of $68.0 \%$ on the 2oth day of control. At the same time, it was noted that larvae grown in wheat bran showed $19.66 \%$ less

viability, and larvae grown in duckweed were $6.0 \%$ more. On the 25th day of control, the larvae of the TMO-2 variant grown in azolla showed a viability of $64.67 \%$, viability of $16.5 \%$ lower than that of larvae grown in wheat bran, and $5.84 \%$ more than in larvae grown in duckweed. On the last day of the study, the larvae of the TMO-2 variant grown in azolla showed a survival rate of $63.37 \%, 16.46 \%$ less than that of larvae grown in wheat bran, and $12.87 \%$ more than that of larvae grown in duckweed. The average survival of the larvae 
of the TMO-6 variant grown in azolla was

$65.0 \%$ (Fig. 9).

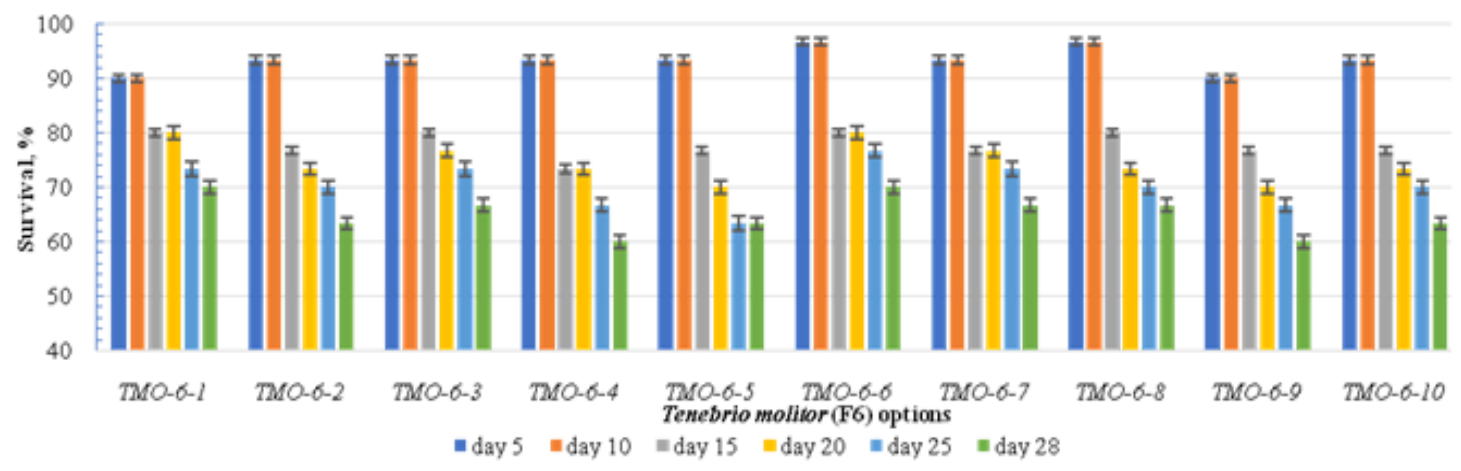

Figure 9. Survival of Tenebrio molitor larvae (TMO-6) in Azollacarolinaflour, \%

While the larvae of the TMO-6 variant averaged $93.33 \%$ during the first ten days of control, $0.67 \%$ less than the larvae of the TMO2 variant in the same period of time, $2.5 \%$ less than the larvae grown on wheat and duckweed.

On the 15th day of observation, the larvae of the TMO- 6 variant grown in azolla had a survival rate of $77.67 \%$, while the survival rate was $1.66 \%$ higher than that of the larvae of the TMO-2 variant, $16.33 \%$ higher than in larvae grown on wheat, and 3.83\% higher than in larvae grown in duckweed. On the 20th day of the study, larvae of TMO-6 grown in azolla showed a viability of $74.67 \%, 6.67 \%$ more than the variant TMO-2, $13.0 \%$ less than the larvae grown on wheat, and $12.5 \%$ more than duckweed larvae. On the 25th day of observation, the larvae of the TMO- 6 variant grown in azolla showed an average viability of $70.33 \%$. This figure was $5.66 \%$ higher than that of the larvae of the TMO-2 variant grown in azolla.

It was found that the larvae of the TMO-6 variant grown in Azolla had a viability of $65.0 \%$ on the 28th day of the study, while the survival

rate was $1.33 \%$ higher than that of the TMO-2 variant. It was noted that larvae grown on wheat bran showed a survival rate of $14.83 \%$ less than larvae grown on duckweed, and $14.5 \%$ higher survival rate. It is worth explaining that the survival rate of larvae grown in wheat bran is $15.5 \%$ higher than the survival rate of larvae grown in azolla, not due to the supply of protein in the sources, but due to the amount of moisture in it.

Moisture (9.58-10.12\%) in wheat bran (protein $15 \%$ ) may have served as a factor in higher viability of larvae than in azolla (protein-27\%, moisture content 8.2\%). Although duckweed flour (protein-16.1\%, humidity-4.4\%) is poorly synthesized in the body of larvae, it is $3.8 \%$ less than that of azolla, which can be explained by the fact that the survival of the larvae is lower than that of wheat and azolla.

In Figure 10 shows the viability of the larvae of the Tenebrio molitor $F_{6}$ generation in cross section of the studied food sources. In particular, the larvae of the TMO-2 variant showed $72.33 \%$, the larvae of the TMO-6 
variant showed a viability of $63.67 \%$ in wheat

medium. bran and an average of $79.83 \%$ in the nutrient

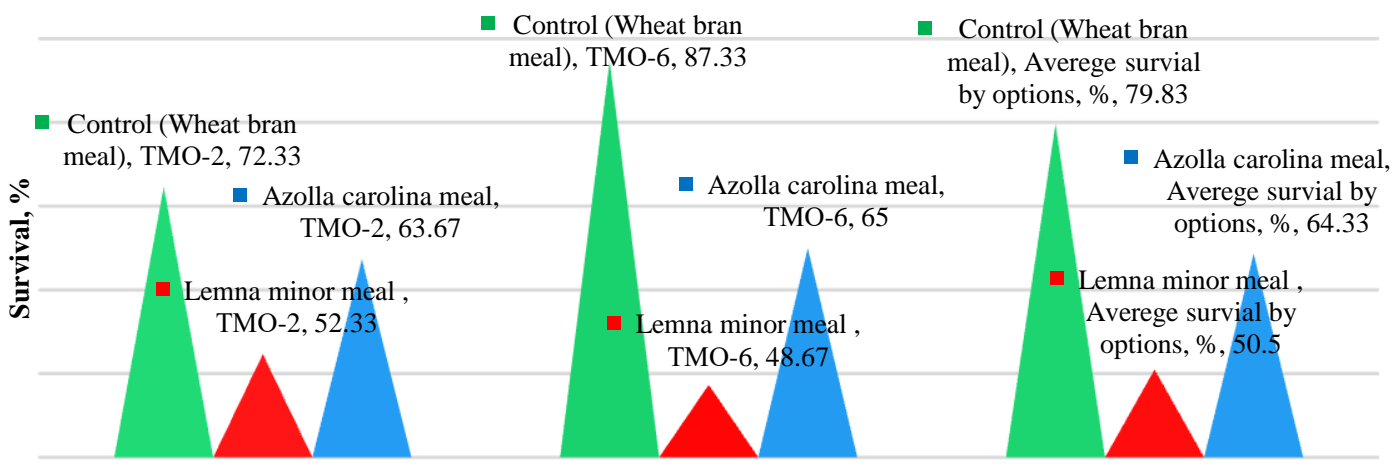

Experiment options

- Control (Wheat bran meal) $\square$ Lemna minor meal $\backsim$ Azolla carolina meal

Figure 10. Survival of Tenebrio molitor $\left(\mathrm{F}_{6}\right)$ larvae in culture media

This indicates that their survival in this culture medium is 0.79. It was found that the larvae of the TMO-2 variant grown on the basis of duckweed averaged $52.33 \%$, the larvae of the TMO-6 variant were $48.67 \%$, and the average viability by food sources was $50.5 \%$. According to this food source, the larvae have a survival rate of 0.50. It was observed that the larvae of the TMO-2 variant grown in Azolla were $63.67 \%$, the larvae of the TMO-6 variant were $65.0 \%$, and the average survival for the food source was $64.33 \%$. In this food source, the larvae survival was 0.64 .

\section{CONCLUSION}

Usually in the production of Tenebrio molitor under controlled conditions and on the basis of which such expensive and inconvenient soya flour, wheat bran, corn bran, cornmeal, beer and alcohol bard, grape waste (cake) are used in the production of feed products. This suggests the need for alternative food sources to organize industrial production based on food insects.

As such alternative sources of nutrients, macrophytes can be considered as one of the most viable options. Favorable climatic conditions in the Republic of Uzbekistan, sunny days at least 270 days a year, from March to mid-November, allow macrophytes (duckweed, azolla, euchornia, pitsiya, etc.) to be grown on an industrial basis. Based on our scientific studies, it was proved that 154 t/ha/year of wet biomass or 27.34 tons of dry weight can be obtained on the basis of Lemna minor in Uzbekistan [Khujamshukurov et al., 2012]. This will allow to establish the production of food insects in Uzbekistan and provide it with a food base based on macrophytes. In our study, survival rates for Tenebrio molitor based on macrophytes in their wheat bran and macrophyte-based nutrient sources were reported. In particular, the survival rates of Tenebrio molitor $F_{6}$ larvae were determined in three different moisture compositions and sources (wheat bran, Lemna 
minor, and Azollacarolina flour). When the Tenebrio molitor $\mathrm{F}_{6}$ larvae of the TMO-2 and TMO-6 generations were grown on wheat bran, the average survival rate was 0.79 ha, duckweed 0.50, and azolla flour 0.64. Summing up the survival rates of Tenebrio molitor $F_{6}$ larvae in the studied nutrient media, it was shown that the average survival was 0.96. This allows you to create a breeding ground with a new content, high nutritional value and low cost, based on the established ratios of wheat bran, duckweed and azolla flour. As a result, the production of feed based on feed insects Tenebrio molitor will provide the fast-growing fish industry in Uzbekistan with a source of continuous, full nutritional value. Growing these types of insects using macrophytes of duckweed and azolla, which are easy to breed, will reduce their cost and increase their nutritional value.

Typically, agricultural products such as soybean meal, wheat bran, corn bran and cornmeal, which are expensive and inconvenient to grow, are used in the production of Tenebrio molitor under controlled conditions and in the production of feed products based on it. This suggests the need for alternative food sources to organize industrial production based on food insects. As such alternative nutrient sources, macrophytes can be considered as one of the most viable options. Favorable climatic conditions in the Republic of Uzbekistan, sunny days for at least 270 days a year, from March to mid-November, allow the cultivation of macrophytes (duckweed, azolla, euchronia, pistia, etc.) on an industrial basis.Based on just one lem Lemna spp. production capacities of 60-145 t/ha/year in Thailand-Vietnam were noted [Landolt and Kandeler, 1987], 36-51 t/ha/year in Israel [Leng et al., 1995], 7-8 t/ha/year in Russia [FAO, 2001], 7-15 t/ha/year in Uzbekistan [FAO, 2001], 22-34 t/ha/year in Germany [Mkandawire and Dudel, 2005], 3070 t/ha/year in India [Leng at al. , 1995], 30 t/ha/year in Egypt [Landolt and Kandeler, 1987] and 57-185 t/ha/year in various regions of the USA [FAO, 2001].

Now it is clear that these numbers have increased several hundred times. In particular, based on our scientific studies, it was proved that in Uzbekistan, on the basis of the small lemna, it is possible to obtain $154 \mathrm{t} / \mathrm{ha}$ /year of wet biomass or 27.34 tons of dry mass [Khujamshukurov et al., 2011]. This will allow to establish production based on food insects in Uzbekistan and provide its food base based on macrophytes. From scientific sources it is known that when obtaining protein based on Tenebrio molitor, very few land areas, feed and water are required in comparison with the land plots necessary for raising chickens, pigs or cattle. In addition to its low environmental impact, this production is characterized by a very high level of productivity and the ability to organize the production process regardless of the time of year. In particular, cattle or pigs cannot feed on any plant matter, and very large plants, including macrophytes, can be used for insects.

In our study, their properties of protein synthesis during the propagation of Tenebrio molitor based on macrophytes were demonstrated. The production of feed based on feed insects will provide the fast-growing fish industry in Uzbekistan with a source of continuous, full nutritional value. The cultivation of these species of insects using macrophytes of duckweed and azole, which 
are easy to breed, will reduce their cost and increase their nutritional value.

\section{ACKNOWLEDGEMENTS}

This study was conducted as part of the scientific program of the Tashkent Institute of Chemical Technology "Development of feeding technology based on non-traditional sources" and this study was carried out as part of an innovative project of the Ministry of Innovative Development of the Republic of Uzbekistan No. I-OT-2019-21.

\section{REFERENCES}

1. Adámková A., Kouřimská L., Borkovcová M., Kulma M., Mlček J. 2016. Nutritional values of edible Coleoptera (Tenebrio molitor, Zophobasmorio and Alphitobiusdiaperinus) reared in the Czech Republic. Potravinarstvo Scientific Journal for Food Industry 10(1), 663-671.

2. Akhtar Y., Isman Y.2018. Insects as an Alternative Protein Source. Proteins in Food Processing. 10. pp.263-288. https://doi.org/10.1016/B978-0-08-1007228.00011-5.

3. Azzollini D., Derossi A., Fogliano V., Lakemond C.M.M., Severini C. 2018. Effects of formulation and process conditions on microstructure, texture and digestibility of extruded insect-riched snacks. Innov. FoodSci. Emerg. Technol. 45: 344-353.

4. Bairagi A., Sarkar-Ghosh K., Sen S.K., Ray A.K.. 2002. Duckweed (Lemnapolyrhiza) leaf meal as a source of feedstuff in formulated diets for rohu (Labeorohita Ham.) fingerlings after fermentation with a fish intestinal bacterium. Bioresour. Technol. 85:17-24.

5. Berggren Å., Jansson A., Low M. 2019. Approaching Ecological Sustainability in the Emerging Insects-as-Food Industry. TrendsEcol. Evol. 34:132-138.

6. Boscou D., Blekas G., Tsimidou M. 2006. Olive oil composition. In: Chemistry, properties, health effects. Rome: AOCS Press, pp. 41-72.

7. Bukkens S. G. F. 1997. The nutritional value of edible insects. Ecol. Food Nutr. 36 (2-4), 287-319.

8. Bukkens S.G.F. 2005. Insects in the human diet: Nutritional aspects. In Ecological Implications of Minilivestock (Role of Rodents, Frogs, Snails, and Insects for Sustainable Development); Paoletti, M.G., Ed.; New Hampshire, Science Publishers: New Ipswich, NH, USA. pp.545-577.

9. Collavo A., Glew R.H., Huang YS., Chuang LT., Bosse R., Paoletti M.G. 2005. House Cricket Small-scale Farming// Ecological Implications of Minilivestock. Pp.515-540.

10. Caruso D., Devis E., Subamia IW., Talamond P., Baras E. 2014. Technical handbook of domestication and production of DipteraBSF. IRD ED., IPB Press.

11. Diener S., Zurbrügg C., Tockner K. 2009. Conversion of organic material by black soldier fly larvae: establishing optimal feeding rates. Waste Management Research. 27(6):603-610.

12. Decree of the President of the Republic of Uzbekistan, 2017, DP 2939.

13. Ekpo K.E. 2011. Effect of processing on the protein quality of four popular insects 
consumed in Southern Nigeria. Arch. Appl. Sci. Res. 3:307-326.

14. FAO. 2001. Duckweed: A tiny aquatic plant with enormous potential for agriculture and environment. FoodandAgriculturalOrganization, Geneva. Pp.108.

15. FAO. 2009. FAO's Director-general on how to feed the world in 2050. Popul. Dev. Rev. 35, 837-839. doi:10.1111/j.17284457.2009.00312.x.

16. FAO/WUR. 2014: Insects to feed the world: summary report. In: Vantomme, P., Münke, C., van Huis, A., van Itterbeeck, J., Hakman, A. (Eds.): Insects to Feed the World. Ede, Netherlands.

17. Fitzpatrick J.J., Iqbal T., Delaney C., Twomey T., Keogh M.K. 2004. Effect of powder properties and storage conditions on the flowability of milk powders with different fat contents. J. FoodEng. 64: 435444.

18. Finke M. D. 2002. Complete nutrient composition of commercially raised invertebrates used as food for insectivores. Zoo Biology 21(3), 269-285.

19. Foley Jonathan A., RamankuttyNavin, Brauman Kate A., Cassidy Emily S., Gerber James S., Johnston Matt, Nathaniel D. Mueller, Christine O'Connell, Deepak K. Ray, Paul C. West, Christian Balzer, Elena M. Bennett, Stephen R. Carpenter, Jason Hill, Chad Monfreda, Stephen Polasky, Johan Rockstro"m, John Sheehan, Stefan Siebert, David Tilman\& David P.M.Zaks. 2011. Solutions for a cultivated planet//Nature. Vol.478. Pp.-337-342. doi:10.1038/nature10452).

20. Gerber P.J., Steinfeld H., Henderson B., Mottet A., Opio C., Dijkman J., Falcucci A., Tempio G. 2013. Tackling climate change through livestock - A global assessment of emissions and mitigation opportunities. Food and Agriculture Organization of the United Nations (FAO), Rome. Pp.-139.

21. Jeon YH., Son YJ., Kim SH., Yun EY., Kang HJ., Hwang IK. 2016. Physicochemical properties and oxidative stabilities of mealworm (Tenebrio molitor) oils under different roasting conditions. Food Sci. Biotechnol. 25: 105-110.

22. Jokic S., Sudar R., Svilovic S., Vidovic S., Bilic M., Velic D., et al. 2013. Fatty acid composition of oil obtained from soybeans by extraction with supercritical carbon dioxide. Czech J. Food. Sci. 31: 116125.

23. Landolt E., Kandeler E. 1987. The Family Lemnaceae: A monographic study (vol.2) Phytochemistry, Physiology, Application, Bibliography, Verof-fentlichungen des Geobotanischen Institutes der ETH 1, Stiftung Rubel, Zurich. Pp.638.

24. Leng RA., Stambolie JH., Bell R. 1995. Duckweed- a potential high-protein feed resource for domestic animals and fish Livestock Research for Rural Development 7.

25. Mekonnen M.M., Hoekstra A.Y. 2012. A Global Assessment of the Water Footprint of Farm Animal Products// Ecosystems, 15:401-415. DOI: 10.1007/s10021-011-9517-8).

26. Mkandawire M., Dudel EG. 2005. Accumulation of arsenic in Lemna gibba L. (duckweed) in tailing waters of two abandoned uranium mines in Saxony, Germany. ScienceofthetotalEnvironment. 336:81-89.

27. Oonincx D.G., van Itterbeeck J., Heetkamp M.J., van den Brand H., van Loon J.J., van Huis A. 2010. An exploration on greenhouse gas and ammonia production 
by insect species suitable for animal or human consumption. PLoS ONE. Pp. 14445.

28. Oonincx D.G., Van der Poel A.F. 2011. Effects of diet on the chemical composition of migratory locusts (Locustamigratoria). Zoo Biology.30(1):916.

29. Olorunfemi T.O.S., Aderibigbe F. M., Alese B. K., Fasakin E.A. 2006. Utilization of duckweed (Lemnapaucicostata) in least cost feed formulation for broiler starter: A linear programming analysis. J. Inf. Technol. 5:166-171.

30. Popa V-M., Gruia A., Raba D-N., Dumbrava D., Moldovan C., Bordean D., et al. 2012. Fatty acids composition and oil characteristics of linseed from Romania. J. Agroalm. Process Technol. 18: 136-140.

31. Ravzanaadii N., Kim S.H., Choi W.H., Hong S.J., Kim N.J. 2012. Nutritional value of mealworm, Tenebrio molitor as food source. International Journal of Industrial Entomology. 25(1):93-98.

32. Ramos-Elorduy J., Pino Moreno J.M., Martinez Camacho V.H. 2012. Could grasshoppers be a nutritive meal. FoodNutr. Sci. 3:164-175.

33. Ramos-Elorduy J., Moreno J.M., Prado E.E., Perez M.A., Otero J.L., De Guevara O.L.1997. Nutritional value of edible insects from the State of Oaxaca, Mexico. J. FoodCompos. Anal. 10:142-157.

34. Rumpold BA, Schluter OK. 2013. Nutritional composition and safety aspects of edible insects. Mol. Nutr. Food Res. 57(5): 802-823.

35. Rojas O.J., Liu Y., H.H.Stein 2014. Concentration of metabolizable energy and digestibility of energy, phosphorus, and amino acids in Lemna protein concentrate fed to growing pigs. J. Anim. Sci. 92:5222-5229.

36. Steven A., Cohen Daviel J. Amino acid analysis utilizing phenyl isothiocyanate derivatives // Jour. Analytical Biochemistry. 1988. V.17. № 1. P.1-16.

37. Scoups R. Methods cleaning proteins. Moscow. 1985. Pp.341-342C.

38. van Huis A., Van Itterbeeck J., Klunder H., Mertens E., Halloran A., Muir G., Vantomme P. 2013. Edible insects - Future prospects for food and feed security. FAO Forestry, Paper 171.

39. Veldkamp T., van Duinkerken G., van Huis A., Lakemond C.M.M., Ottevanger E., Bosch G., van Boekel M.A.J.S. 2012. Insects as a sustainable feed ingredient in pig and poultry diets - a feasibility study. Rapport 638 -Wageningen Livestock Research.

40. Vrabec V., Kulma M., Cocan D. 2015. Insects as an alternative protein source for animal feeding: a short review about chemical composition. Bulletin of the University of Agricultural Sciences \& Veterinary Medicine Cluj-Napoca Animal Science \& Biotechnologies. 72(2):116-126.

41. Haustein A.T., Gilman R.H., Skillicorn P. W. 1994. Performance of broiler chickens fed diets containing duckweed (Lemna gibba). J. Agric. Sci. 122:285-289.

42. Hasan M.R., Chakrabarti R. 2009. Floating aquatic macrophytes - Duckweeds. In: M. R. Hasan and R. Chakrabarti, editors, Use of algae and aquatic macrophytes as feed in smallscale aquaculture. Food and Agric. Organ. of the U. N., Rome. p. 29-52.

43. Kamler E. 2012. Early Life History of Fish: An Energetics Approach; Springer Science \& Business Media: Berlin, Germany. Volume 4, p.72. 
44. Khujamshukurov N.A. 2011. Alternative protein products. J. XXItechnology.4(5):14-15.

45. Khujamshukurov N.A., Nurmuxamedova V.Z. 2016. Production feed: modern trend and development aspect. Scientificoverview. J. Zooveterinary. №8 (105):34-37.

46. Smil V. 2002. Food production. In the Nutrition Transition; Academic Press: San Diego, CA, USA. Pp.25-50.

47. Steinfeld H., Gerber P., Wassenaar T.D., Castel V., Rosales M., Rosales M., de Haan C. 2006. Livestock's Long Shadow: Environmental Issues and Options; FAO: Rome, Italy.

48. Tran G., Heuzé V., Makkar H.P. 2015. Insects in fish diets. Anim. Front. 5: 37-44.

49. Zieli'nska E., Baraniak B., Kara's M., Rybczy 'nska K., Jakubczyk A. 2015. Selected species of edible insects as a source of nutrient composition. FoodRes. Int. 77: 460-466.

50. Zhao X., Vázquez-Gutiérrez J.L., Johansson D.P., Landberg R., Langton M. 2016. Yellow mealworm protein for food purposes. Extraction and functional properties. PLoS ONE. 11, e0147791. 